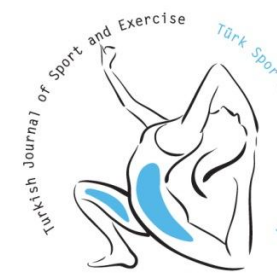

ISSN: 2147-5652

\title{
Examination of state-trait anxiety levels of elite athletes according to some variables
}

\author{
Burak GURER ${ }^{1}$, Ilhan Adilogullari², Hacı Murat SAHIN ${ }^{1}$
}

${ }^{1}$ School of Physical Education and Sport, Batman University, Batman, Turkey.
${ }^{2}$ School of Physical Education and Sport, Çanakkale Onsekiz Mart University, Çanakkale, Turkey.
Address correspondence to H. Murat Sahin, hmuratsahin@gmail.com.

\begin{abstract}
In this study it is aimed to examine state-trait anxiety points of elite athletes prior to and after competition in terms of several variables. 64 athletes, who competed in the branches of Judo, taekwondo and weightlifting of Turkish National Team during Mediterranean Games, attended this study. The data of the study is obtained by using the State-Trait Anxiety Inventory-STAI which is developed by Spielberger, Gorsuch, Lushene and later adapted by Oner and Le Compte. Scales are applied to athletes prior to and after the tournament. The state anxiety points of athletes after the competition are found to be significantly low compared to the points prior to the competition. This study demonstrates parallelism with our results. In conclusion, it would not be wrong to say that the ages of athletes affect trait anxiety level. When age variable is taken into consideration trait anxiety has become effective again. Thus, increasing age of elite athletes affects trait anxiety formation.
\end{abstract}

Keywords: Anxiety, state anxiety, trait anxiety, athletes.

\section{INTRODUCTION}

Athletes might be under the influence of several psychological factors that affect their performance positively or negatively during a competition or tournament. These factors sometimes can be related to the personality structure of an athlete or might occur because of an external stimulus as well. Anxiety is one of the psychological factors that affect performance (24).

Anxiety can be accepted as a broad concept for several highly complicated emotional and incentive (motivating) situations as a result of a threat. This threat is about subjective evaluation of a situation, and in the course of performance and social situations, physical threat, lack of confidence or uncertainty it is harmful for the self-esteem of a person (20).

Psychologically anxiety is examined in three dimensions. These are cognitive, physical and behavioral dimensions (15). These dimensions are defined as the following. Cognitive anxiety includes negativity because of evaluation of both principal and situational factors (21). The term includes negative thoughts of an athlete about his/her current performance and intense negative thoughts for his/her future performance. Cognitive anxiety especially indicates negative expectations about a person, cognitive worries, current situation and potential outcomes of this situation (17). In general, cognitive anxiety has a weakening effect on athletic performance (9). Dunn (11) has determined four core elements in cognitive anxiety analysis of ice hockey players; 1- Fear of failure related to performance, 2- Worries related to negative social evaluation, 3- Worries related to injury or physical danger and 4- Uncertain fear related to unknown.

Second component of the anxiety structure includes somatic and physical processes. Substantial indications of physical anxiety are autonomic stimulation indications, nervousness and this unpleasant feeling can be defined as tension, and these can be described as perception of anxiety experience and physical and emotional elements (17). Anxiety component in sports manifests itself as fast heartbeat, indications of autonomic nerve, increase in perspiration, shortness of breath, wet hands and the feeling of butterflies in stomach.

Third component is that the anxiety is behavioral. Anxiety indexes include tense, agitative and uneasy facial expressions (15). It is interesting that although it is easy to be perceived, behavioral dimension of anxiety in sports has taken less research attention. However the relationship among cognitive anxiety, somatic anxiety and qualified performance is examined. Anxiety, depending on 
the quality of the duty, has different effects on the performance. If it is necessary to explain worry, it is seen that it prevents athletic performance, fine motor skills and most forms of the somatic anxiety (22).

Anxiety, in the process of an athlete in which he/she displays a high performance, is always associated with emotions (3). According to Cashmore (9), the term of anxiety states an unpleasant emotion. It is a permanent emotion which is characterized with worry and fear. Similarly, Buckworth and Dishman (7) tell that if this emotion, which is defined as worry or a state of worry, or real and certain danger does not exist and then tension would exist.

Anxiety is complicated; it occurs unexpectedly and leads to an increase in the stress levels of elite athletes (8). Emotions have significant place in the lives of athletes and their sporting lives. Although several athletes use sufficient personal strategies for stress management, it is known that elite athletes display weak performance when they lose the control of their emotions during important competitions (1). This study is conducted in order to define anxiety levels of athletes involved in the national teams of judo, taekwondo and weight lifting prior to the competition and examine the relationships among several variables.

\section{METHOD}

\section{Population and Sample}

The population of the study consists of athletes from the national teams, who attended Mediterranean Games on the date of 20-30th June,
2013. The sample is restricted with three branches as the organization is crowded and performed on a wide area. The research group consists of 64 athletes of Turkish National Team within the branches of judo, taekwondo and weight lifting during Mediterranean Games, 2013.

\section{Data Collection Tool}

In this study, State-Trait Anxiety InventorySTAI is used in order to measure the level of anxiety of national team athletes (18). This scale is developed by Spielberger, Gorsuch, Lushene, its validity is checked by Oner and Le Compte and used in different studies. State anxiety scale is a scale which includes 20 items that define how an individual feels under certain circumstances at certain times. Trait anxiety scale is a scale which includes 20 items that define how an individual feels independent of circumstances and conditions (2).

\section{Data Collection}

Data is collected by a researcher during Mediterranean Games, on 20-30th June, 2013. Related scales are applied to athletes from national teams of judo, taekwondo and weight lifting while collecting the data. Scales are collected in two stages, one hour before and one hour after the competition.

\section{Data Analysis}

Data is analyzed by using SPSS 16.0. In order to determine the differences between anxiety points, the paired t-test is used. Correlation analysis is used for the relationship between anxiety points and variables. Results are examined basing on $\mathrm{p}<0.05$ significance level.

\section{RESULTS}

Table 1. Comparison of state anxiety levels of national athletes prior to and after competition.

\begin{tabular}{lllccc}
\hline Anxiety Type & $\mathrm{N}$ & Mean & Std. Deviation & $\mathrm{t}$ & $\mathrm{P}$ \\
\hline State Anxiety Prior to Competition & 64 & 42.78 & 5.84 & 1.38 & 0.22 \\
State Anxiety After Competition & 64 & 41.61 & 4.43 & & \\
\hline
\end{tabular}

Table 2. Comparison of trait anxiety levels of national athletes prior to and after competition.

\begin{tabular}{|c|c|c|c|c|c|}
\hline Anxiety Type & Mean & $\mathrm{N}$ & Std. Deviation & $\mathrm{t}$ & $\mathrm{P}$ \\
\hline Trait Anxiety Prior to Competition & 42.14 & 64 & 7.20 & \multirow{2}{*}{8.12} & \multirow{2}{*}{$0.00^{*}$} \\
\hline Trait Anxiety After Competition & 35.70 & 64 & 4.49 & & \\
\hline
\end{tabular}

Table 3. Comparison of state anxiety levels of national athletes according to their ages.

\begin{tabular}{lllrr}
\hline & Mean & $\mathrm{N}$ & Std. Deviation & $\mathrm{r}$ \\
\hline Age & 21.38 & 64 & 2.87 & 5.84 \\
State Anxiety Prior to Competition & 42.78 & 64 & 0.11 & 0.38 \\
State Anxiety After Competition & 41.61 & 64 & 0.43 & 0.09 \\
\hline
\end{tabular}


Table 4. Comparison of trait anxiety levels of national athletes according to their ages.

\begin{tabular}{lccccc}
\hline & Mean & $\mathrm{N}$ & Std. Deviation & $\mathrm{r}$ & $\mathrm{P}$ \\
\hline Age & 21.38 & 64 & 2.87 & & \\
Trait Anxiety Prior to Competition & 42.14 & 64 & 7.20 & 0.24 & 0.05 \\
Trait Anxiety After Competition & 35.70 & 64 & 4.49 & 0.30 & $0.01^{*}$ \\
\hline${ }^{*} \mathrm{p} \leq 0.05$ & & & &
\end{tabular}

\section{DISCUSSION}

In this study, state-trait anxiety points of elite athletes prior to and after competition are examined. In Table 1 , by using t-test it is found that state-trait anxiety points of elite athletes prior to and after competition did not change significantly. However, it is seen that state anxiety points prior to competition (SAPPC) (42.78) is higher than state anxiety points after competition (SAPAC) (41.68). This reduction of anxiety points might be because of relief after a match. In Bingol et al.'s study titled as "Determine the Anxiety Level of National Team Taekwondo Athletes before Matches Who Studied at Universities" it is seen that athletes have high anxiety points before matches (6). This finding demonstrates similarity with our research results. In Engur's study titled as "The Effect of Achievement Motivation on State Anxiety Levels of Elite Athletes", when average points of "State Anxiety" level of athletes that are interested in team sports and that are interested in individual sports are considered, it is seen that there is a statistically significant difference between the athletes interested in team sports and individual sports (12). According to this, average points of "state anxiety" of athletes interested in team sports are found to be significantly high compared to athletes interested in individual sports. The lower anxiety levels of athletes interested in individual sports demonstrate parallelism with our research.

According to Table 2 athletes have significantly higher TAPPC than TAPAC. Karakaya et al. in their studies titled as "Evaluation of Depression, Anxiety and Self-Esteem in Swimmers" (16) found that SAPPC is higher and this finding supports our research results. The anxiety points of elite athletes may increase during a period of intense competition. It is also known that trainers are one of the factors that increase athletes' levels of anxiety $(4,19)$. In Table, it is seen that SAPPC and SAPAC does not change significantly in terms of age variable. Bingol et al. in their study with national teakwondo athletes who are university students (6), Dorak ve Şefik (10) in their study which is conducted with handball players who play in the first league, Erbas (13) in his study with second league basketball players, Erbas ve Küçük (14) in their multiple studies with top level basketball players could not find a statistically significant relationship between anxiety points and age variable.

According to Table 4 there is a positive correlation between TAPAC and age variable $(\mathrm{r}=0.30, \mathrm{p}<0.01)$. It is seen that TAPAC increases together with the ages of athletes. From this point of view, senior athletes' having trait anxiety could be related to the fear of not being chosen for the national team. Besides, senior athletes' having high scores of trait anxiety could be related to success of the match. In similar researches different results are found. Many researches which examine the relationship between anxiety and performance duties, demonstrate that athletes with high anxiety make more mistakes compared to athletes that have low anxiety level (23). According to this fact, it could be concluded that senior athletes would think that they make a mistake and this situation affects their anxiety levels. In a different study, sports branches are examined in terms of trait anxiety point and it is found that taekwondo athletes have high points of anxiety (5). This situation may be related to one to one competitive sport. This study demonstrates parallelism with our results. In conclusion, it would not be wrong to say that the ages of athletes affect trait anxiety level. When age variable is taken into consideration trait anxiety has become effective again. Thus, increasing age of elite athletes affects trait anxiety formation.

\section{REFERENCES}

1. Anshel MH. Sport Psychology: from theory to practice, Ediția a III-a, Gorsuch, 1997.

2. Aydemir Ö, Köroğlu E. Clinical Scales that are used in Psychiatry. Physicians Publication Union, Ankara: Medicographics Agency and Printing, 2000.

3. Baban A. Stres şi personalitate. ediția I, Cluj-Napoca, Editura Presa Universitară Clujeană, 1998.

4. Baker J, Cote J, Hawes R. The relationship between coaching behaviours and sport anxiety in athletes. J Sci Med Sport, 2000; 3: 110-119.

5. Başaran MH, Taşğın Ö, Sanioğlu A, Taşkın AK. Examination of the level of state-trial anxiety of sportsmen according to some variables. Selçuk University Journal of Social Sciences Institute, 2009; 5(21): 533-542.

6. Bingöl H, Çoban B, Bingöl Ş, Gündoğdu C. Determine the anxiety level of national team taekwondo athletes before matches who studied at universities. Selçuk University 
Journal of Physical Education and Sports Science, 2012; 14(1): 121-125.

7. Buckworth J, Dishman RK. Exercise Psychology. Champaign, IL: Human Kinetics, 2002.

8. Butt J, Weinberg R, Horn TS. The intensity and directional interpretation of anxiety: fluctuations throughout competition and relationship to performance. The Sport psychologist, 2003; 17(1): 35-54

9. Cashmore E. Sport Psychology: Key Concepts. London: Routledge. Coach matters. Scand J Med Sci Sports, 2002; 12: 54-59.

10. Dorak F, Şefik T. The Reasons of Success and Failure of Athletes, Journal of Sport Sciences, 1991; 2(5): 24-27.

11. Dunn JGH. A theoretical framework for structuring the content of competitive worry in ice hockey. Journal of Sport \& Exercise Psychology, 1999; 21: 259-79.

12. Engür M. The Effect of achievement motivation on state anxiety levels of elite athletes. Ege University Institute of Medical Sciences (Master's Thesis), Izmir, 2002.

13. Erbaş M. (2000). Examination of the effects of several personal variables of the players in 2nd men's basketball league on state anxiety and the effects of state anxiety on the relationships within teams, Trakya University Institute of Medical Sciences Department of Physical Education and Sports (Master's Thesis), Edirne, 2000

14. Erbaş MK, Küçük V. Comparisons of the state anxiety level according to the different variables in top level basketball players. Selçuk University Journal of Physical Education and Sports Science, 2012; 14(2): 257-261.

15. Gould D, Greenleaf C, Krane V. Arousal-Anxiety and Sport', in T. Horn (ed.), Advances in Sport Psychology (2nd edn, pp. 207-41). Champaign, IL: Human Kinetics, 2002.

16. Karakaya I, Ayşen C, Belma A. Evaluation of depression, anxity and self-esteem levels in swimmers. Anatolian Journal of Psychiatry, 2006; 7: 162-166.

17. Morris L, Davis D, Hutchings C. Cognitive and emotional components of anxiety: literary review and revised worryemotionality scale. Journal of Educational Psychology, 1981; 73: 541-55.

18. Öner N, Durumluluk, sürekli kaygi envanterinin türk toplumunda geçerliliği (Thesis), Tezi, Ankara, 1977.

19. Pensgaard AM, Roberts GC. Elite athletes' experiences of the motivational climate: the coach matters. Scandinavian Journal of Medicine \& Science in Sports, 2002; 12(1): 54.

20. Pijpers JR, Oudejans RD, Holsheimer F, Bakker FC. Anxietyperformance relationships in climbing: a process-oriented approach. Institute for Fundamental And Clinical Human Movement Sciences, Psychology of Sport and Exercise, 2003 4(4): 283-304.

21. Smith R, Smoll F, Wiechman SA. Measurement of Trait Anxiety in Sport. In J.L. Duda (ed.), Advances in Sport and Exercise Psychology Measurement (pp. 105-27). Morgantown, WV: Fitness Information Technology, 1998.

22. Spielberger CS. Theory and Research on Anxiety. In C.S. Spielberger (ed.), Anxiety and Behavior (pp. 3-20). New York: Academic Press, 1966.
23. Yılmaz V, Koruç Z. The Relationship between anxiety levels before and after competition performance. 8th International Sports Sciences Congress, 2004.

24. Yücel EO. Determine the anxiety level of national team taekwondo athletes before matches who studied at universities. Gazi University Institute of Health Sciences Department of Physical Education and Sports Master's Thesis, Ankara, 2003. 